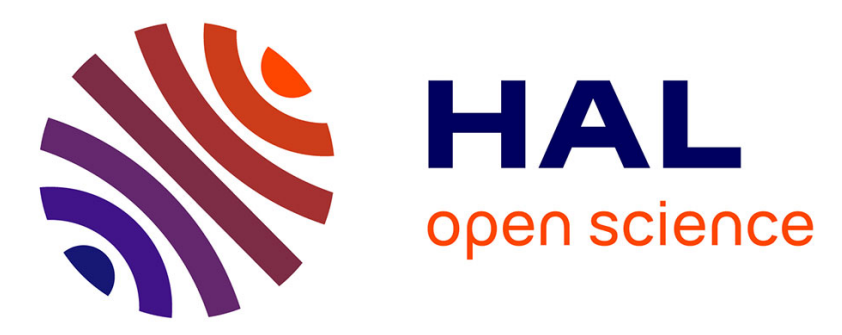

\title{
Firm voluntary measures for environmental changes, eco-innovations and CSR : Empirical analysis based on data surveys
}

Christian Le Bas, Nicolas Poussing

\section{- To cite this version:}

Christian Le Bas, Nicolas Poussing. Firm voluntary measures for environmental changes, ecoinnovations and CSR : Empirical analysis based on data surveys. 2014. halshs-00838005v2

\section{HAL Id: halshs-00838005 \\ https://shs.hal.science/halshs-00838005v2}

Preprint submitted on 16 Jan 2014

HAL is a multi-disciplinary open access archive for the deposit and dissemination of scientific research documents, whether they are published or not. The documents may come from teaching and research institutions in France or abroad, or from public or private research centers.
L'archive ouverte pluridisciplinaire HAL, est destinée au dépôt et à la diffusion de documents scientifiques de niveau recherche, publiés ou non, émanant des établissements d'enseignement et de recherche français ou étrangers, des laboratoires publics ou privés. 
Firm voluntary measures for environmental changes, eco-innovations and CSR:

Empirical analysis based on data surveys

Christian Le Bas, Nicolas Poussing 


\section{GATE Groupe d'Analyse et de Théorie Économique Lyon-St Étienne}

93, chemin des Mouilles 69130 Ecully - France

Tel. +33(0)4 72866060

Fax $+33(0) 472866090$

6, rue Basse des Rives 42023 Saint-Etienne cedex 02 - France

Tel. +33 (0)4 77421960

Fax. +33 (0)4 77421950

Messagerie électronique / Email : gate@gate.cnrs.fr

Téléchargement / Download : http://www.gate.cnrs.fr - Publications / Working Papers 


\title{
Firm voluntary measures for environmental changes, eco-innovations and CSR: Empirical analysis based on data surveys ${ }^{1}$
}

\author{
Christian Le Bas \\ Université de Lyon, F-69007 Lyon; CNRS, GATE Lyon Saint-Etienne, F-69130 Ecully. \\ Université Lyon 2, F-69007 Lyon. Email: christian.lebas@ univ-lyon2.fr
}

\section{Nicolas Poussing}

CEPS/INSTEAD - CREM CNRS, 3, Avenue de la Fonte, L-4364 Esch-sur-Alzette. Email: nicolas.poussing@ceps.lu

\begin{abstract}
Despite the increased strategic importance of environmental innovation on the one hand and corporate social responsibility on the other, there are still few studies that show firm voluntary measures create a primary determinant of environmental changes. First, we clarify the meaning of voluntary measures and CSR. Second, we utilize a survey carried out in Luxemburg on firm CSR practices jointly with the Community Innovation Survey 2008 (CIS 2008). We merge them and show through the estimation of a probit model that CSR is an important factor that explains environmental innovation. Thanks to a question from CIS 2008 we can contribute to the literature by developing a new indicator measuring the scale of the positive impacts on the environment coming from the firm technological innovation capacity. A negative binomial regression enables us to estimate a significant and positive effect of CSR and firm value on this scale.
\end{abstract}

Key words: environmental innovation, corporate social responsibility, Community Innovation Survey 2008, innovation impacts on the environment

JEL classification : D22, H23, L21, 031

Résumé

Malgré l'importance stratégique croissante des innovations environnementales et des comportements de responsabilité sociale il y a encore peu de recherche qui montre que les mesures volontaires des entreprises constituent un déterminant des changements environnementaux. Dans cet article on clarifie premièrement ce qu'il faut entendre par mesures volontaires et par comportements de responsabilité sociale (RSE). En second lieu on utilise une enquête menée au Luxembourg sur les pratiques de RSE des firmes en complément de l'enquête communautaire 2008 sur l'innovation (CIS 2008). Après avoir fusionné les deux on estime un modèle probit qui montre que la RSE est un important facteur expliquant l'innovation environnementale. A partir de l'enquête CIS 2008 on contribue à la littérature en proposant un nouvel indicateur mesurant l'échelle des impacts positifs sur l'environnement due à la capacité d'innovation des firmes. Un modèle de régression binomial négatif permet d'estimer un effet positif et significatif de la RSE et des valeurs de l'entreprise sur cette variable.

\footnotetext{
${ }^{1}$ Paper presented at the European Society for Ecological Economics Conference. Lille, 18-21 June 2013.

The underlying research for this paper was partly funded by Region Rhône-Alpes (Program ARC8, Industrialisation et Sciences de gourvernement). C. Le Bas acknowledges support from CEPS/INSTEAD (Luxembourg).
} 


\section{Environmental innovation in the context of climate change.}

\subsection{The context}

How to cope with climate change (so-called global warming) and environmental concerns (diverse types of pollution, pressure on exhaustible resources) constitutes a big challenge for governments. Public policies aiming to create and diffuse, on a large scale, clean technologies and/or technological systems able to reduce $\mathrm{CO}_{2}$ emissions matter in this context. With respect to these goals, it is not so evident to modify industrial firms' conduct. Discourse among economists focuses mainly on the tools that have to be implemented or on the kind of policy to be launched. We found in the literature discussions on at least three main factors for exerting environmental changes: taxes, complying regulation, and incentives to invest in R\&D of green/clean technologies projects (see among the main contributions: Acemoglu et al., 2009; Aghion et al., 2009; Bosetti et al., 2009; Veugelers, 2012). Nevertheless, applied research tends to highlight the necessary complementarity between the diverse tools. For instance, Frondel et al. (2007) show innovations in clean technologies demand both regulation and firm costs saving strategy. Public pressures associated with customers needs set up natural drivers of eco-innovation (Florida, 1996; Horbach, 2008). The role of regulation appears often as the main determinant of eco-innovation ${ }^{2}$ (Belin et al., 2009). Many studies focus on the mechanisms for the tuning of public policy measures (see for instance the work by Veugelers, 2012). It seems that the research in its current state does not sufficiently take into account the positive impact of firm 'voluntary measures' (according to the terms put forth by Bansal and Roth, 2000) in favour of green/clean technologies. By contrast very recently Veugelers (2012), based on the results from the CIS survey for the Flemish region of Belgium, shows the importance of firm 'voluntary measures' as a driver of environmental innovations.

1.2. What does an eco-innovation mean?

A survey launched at the European Community level (thereafter CIS 2008 survey) addresses for the first time, in a systematic manner, the innovations having environmental benefits. The definition adopted by the survey is an environmental innovation (or ecological innovation or more simply eco-innovation) "is a new or significantly improved product (good or service), process, organizational method or marketing method that creates environmental benefits compared to alternatives. The environmental benefits can be the primary objective of the innovation or the result of other innovation objectives. The environmental benefits of an innovation can occur during the production of a good or service, or during the after sales use of a good or service by the end user" (see as well discussions on diverse environmental innovation definitions by Arundel and Kempf, 2009). The important here is an eco-innovation is not necessarily technological.

Before CIS 2008 there were no official statistics for corporate environmental innovations. Scholars and experts had to carry out their own surveys. For instance for Germany, Wagner $(2007,2008)$ uses data from a survey in order to assess the scale of green or clean technology. Horbach (2008) also analyzes data from a survey. But as noted by Ziegler and Nogareda (2009), both data sets are not specifically designed to examine environmental product and process. The work by Frondel et al. (2007) is noteworthy. Their survey on seven Organisation

\footnotetext{
${ }^{2}$ In this paper, eco-innovation, or ecological innovation is another term for environmental innovation. We used here the two terms.
} 
for Economic Co-operation and Development (OECD) countries provides quantitative information on technological environmental innovations. By contrast, the firm-level data set applied in Ziegler and Rennings (2004) and Ziegler and Nogareda (2009) have gathered data on environmental product and process innovations of German manufacturing firms with 50 or more employees. Of course information on patent applications can be used as well for measuring firms and nations' activities in inventive activities devoted to environment protection (see for instance Jaffe and Palmer, 1997), but this has some important limitations (see among other Veugelers, 2012).

What does the CIS 2008 survey tell us about definition innovations at large? Borghesi et al. (2012) used CIS 2008 to study six thousand Italian manufacturing firms concerned by energy efficiency (including $\mathrm{CO} 2$ abatement), a category of environmental innovation. Their two main results are: $R \& D$ does not influence eco-innovation and the acquisition of external knowledge matters most. Galia et al. (2012) used CIS 2008 in relation to the behaviour of French Manufacturing firms. With respect to motivations to introduce eco-innovation voluntary codes or agreements, only $39.5 \%$ of the firms were concerned. As a consequence the authors concluded that the conduct of French firms are more reactive (cost reductions, be in conformity to regulations) than proactive (Chassagnon and Haned, 2013).

\subsection{Aims of the study}

We want to contribute to the current stream of research on the determinants of eco-innovation by focusing our attention on the role of 'voluntary measures'. Indeed the purpose of this study is to assess the supposed positive impact of these "voluntary measures" on environmental changes. Moreover, we argue they can be placed in relation to the development of corporate social responsibility (CSR thereafter), a topic increasingly discussed in the literature. In a few words we want to check if CSR or firm value for society shape a determinant of ecoinnovation. We will suggest a measure for this deemed impact. Many firms argue that they have an environmental responsibility and orient their conduct along the lines of sustainable development. Obviously these 'voluntary measures' cannot alone drive the overall economy towards a sustainable growth path in favour of climate change. Firm environmental awareness certainly has at least two consequences (we exclude here the 'greenwashing' conduct aiming mainly to improve the image of the firm): 1) it gives the firms opportunities to build up new internal (to the firm) competences in green/clean technological activity considered as crucial for acknowledging the potential economic benefits (Porter and van der Linde, 1995); and 2) it can act as a complementary action in relation to compulsory regulation and public incentive measures. In effect, new incentive measures in favour of green/clean technologies are more effective if the firms are already motivated and convinced of the necessary environmental changes.

The paper is structured as follows. Section 2 sets out what voluntary measures for environmental changes means and their relation to CSR. Our data is described in section 3. The last section presents our econometric exercise concerning CSR as determinants of ecoinnovations.

\section{Voluntary measures for environmental changes: definition, forms, and relation to CSR}

Voluntary environmental measures can be defined as "programs, codes, agreements, and commitments that encourage organizations to voluntarily reduce their environmental impact beyond the requirements established by the environmental regulatory system" (Darnall and 
Sides, 2008). It implies, to some extent, a certain strategic commitment. But clearly the scale of such measures differs across firms (from specific individual measures to large programs over a long time period). We found in the literature a large variety of situations of this kind, such as private agreements or collaborations between organizations, public voluntary environmental programs, agreements between private firms, and public agencies and so on ${ }^{3}$. Since 1996, the ISO 14001 norm has been sponsored by the International Organization for Standardization (ISO), an international body of national standards institutions that match standards for the environment management system EMS. Certification according to ISO 14001 requires that a "facility must undertake an initial comprehensive review of its environmental practices and systems, formulate and implement an action plan for environmental management, identify internal governance responsibilities for environmental issues, and have a plan to correct environmental problems" (according to Ziegler and Nogareda, 2009; see also Potoski and Prakash, 2005). It must be noted that such a certification requires third-party audits. In Europe, Eco-Management and Audit Scheme (EMAS) is a management tool for companies to assess, report, and improve their environmental performance. The scheme has been available for participation by companies since 1995 and was originally restricted to companies in industrial sectors. In 2009 the EMAS Regulation was revised and modified for the second time (withdrawn from the website: http://ec.europa.eu/environment/emas/index_en.htm). Notably, ISO 14001 seems to be more attractive than EMAS.

Voluntary environmental measures are sometimes considered in relation to corporate social responsibility (see among others Antonioli and Mazzanti, 2009). Corporate social responsibility (hence after CSR) is also an important piece of this study. We need to give an accurate definition because this notion itself means different things to different people (Lyon and Maxwell, 2008). By CSR we mean a set of rules organizing the process by which companies "integrate social and environmental concerns to their business operations and in their interactions with stakeholders on a voluntary basis" (according to the definition provided by the Commission of the European Communities, 2001, p. 6). CSR practices also address environmental issues on a voluntary basis. The current CSR approaches are generally focused on four main aspects (Garriga and Melé, 2004): (1) meeting objectives that produce long-term profits, (2) using business power in a responsible way, (3) integrating social demands, and (4) contributing to a good society by doing what is ethically correct. Whatever the definition it appears a responsible firm is a firm that does something for the environment on a voluntary basis. Of course it means, at a minimum, to follow diverse regulation in that field, but also going beyond compliance or voluntarily internalizing externalities (Lyon and Maxwell, 2008). The important point here is that firms do it because it matches their values and not mainly for economic purposes. The problem is that it may be that the actions untaken on a voluntary basis are also economically effective for the firm according to a win-win hypothesis put forth by Porter and van der Linde (1995). In others words, CSR practices in the field of environmental innovation in particular could increase firm economic performance. As a consequence it would be absurd to consider good CSR practices as always reducing firm profitability.

In the literature many authors have considered the economic drivers of CSR. For instance Lyon and Maxwell (2008) note that "Perhaps pollution is symptomatic of broader production inefficiencies, and pollution reduction and cost reduction go hand in hand to create "win/win" opportunities in today's economy. Perhaps a new generation of "green" consumers is willing

\footnotetext{
${ }^{3}$ See among others the contributions by Khanna (2001), Koehler (2007), Henriques and Sadorsky (2008).
} 
to pay higher prices for clean products, and firms are simply responding to this shift. Or perhaps business has become savvier about the workings of the political system, taking proactive steps to avert political conflict (e.g., regulatory threats, enforcement pressures, boycott threats ...) rather than reacting to public pressure after the fact". In their view "all of these market and political forces, as well as others, have driven firms to engage in CSR". Our interpretation appears a little different. We basically think the main drivers of CSR are the firm values as far as social or societal issues are concerned. It may be the consequences of CSR practices have positive effects on firm economic performance, but the latter are not in any case the main factor inducing CSR behaviour.

Surprisingly, we found in the literature dealing with CSR a moderately extreme definition that deserves great attention: CSR practices aim to sacrifice profits for the social interest (see the important contributions by Elhauge, 2005 and Reinhadt and Stavins, 2010). We think that this approach tends to view CSR too narrowly ${ }^{4}$. We prefer considering CSR as values-driven whatever the consequences (positive or eventually negative) on the firm's economic performance. Baron (2001) suggested distinguishing two kinds of CSR. CSR which is driven by pure altruism and consequently, is unprofitable, and from "strategic CSR" which naturally is profitable. Lyon and Maxwell (2008) adopt this distinction as well. Nevertheless, in an economic world in which information about firm and firm image can change quickly into intangible assets, it is very easy for the firm to find a return for its CSR practices. More important for us is to finely characterize different types of CSR responses that firms adopt. We use the taxonomy provided by Burke and Logsdon (1996), not so far from the analysis by Porter and Kramer (2006, 2011). They retain two types of CSR: strategic CSR, or proactive CSR, and responsive CSR or reactive CSR. Strategic CSR requires an alignment between CSR and the firm's growth strategy, which then creates a virtuous circle that allows innovation activities to develop. By contrast, responsive CSR corresponds to the most basic level of CSR, that is, "acting as a good corporate citizen, attuned to the evolving social concerns of stakeholders, and mitigating existing or anticipated adverse effects from business activities"' (Porter and Kramer, 2006, p. 85). In fact, here CSR contributes only to incremental improvements, but they are often disconnected from the firm's overall strategy.

For the purpose of our analysis this taxonomy appears richer than the classical opposition between altruistic versus strategic CSR. Bocquet et al. (2012) show the relevance of this taxonomy and found firms with strategic CSR profiles are more likely to innovate in both products and processes (in other words, complex innovators, see Le Bas and Poussing, 2012). It seems to us that the two types of CSR profiles matter in explaining firm innovation behaviour. Interestingly these kinds of CSR are not so far from the two types of reactive behaviours put forth by the 'old' Schumpeter (1947) adaptative and creative responses.

\footnotetext{
${ }^{4}$ We have not exaggerated the relevance of this approach to CSR. Reinhadt and Stavins (2010, p. 175) relevantly argue: “.........evidence on sacrificing profits in the social interest is lacking. The bulk of the available evidence suggests that most firms view socially responsible actions in the same way that they view more traditional business activities, such as advertising and R\&D. Instead of altruistically sacrificing profits, they engage in a more limited - but more profitable — set of socially beneficial activities that contributes to their financial goals. Hence, although proponents of sustainable business practices may argue that being environmentally responsible will inevitably lead to higher profits in the long term, the relationship between socially responsible activities and profitability may be best characterized as some firms will generate long-term profits from some socially responsible activities some of the time...".
} 
All voluntary measures cannot be always considered as related to CSR. Some of them are driven by the search for better technological performance or better competitive positions linked to costs reduction. Here we are primarily concerned by CSR.

\section{Data description: the two surveys}

We based our empirical observations on data coming from two surveys: Luxemburg CSR survey and CIS 2008 carried out in Luxemburg.

The CSR survey was conducted by CEPS/INSTEAD (Luxembourg) in 2008. This survey included enterprises belonging to all economic sectors that have 10 employees or more. Among a population composed of 3,296 companies, a stratified random sampling selected 2,511 firms. We used a questionnaire in French and German (an English version was also available upon request) to collect the data by mail. Data collection was conducted from midSeptember to mid-December. We received 1,144 questionnaires. The survey gives details about the CSR activities of the firms in 2008 (see Poussing (2011) for an overview of the main results). By contrast, CIS 2008 is mainly dedicated to firms' innovation behaviour. The diversity of firm innovative activity is indeed the main topic at the core of CIS 2008.

The CSR Survey does not give information on real firm innovation behaviour. Therefore, we merged the CSR survey and CIS 2008 so that we can obtain information on firm behaviour in terms of CSR and the implementation of innovation regardless of their goals. We obtained a sample of 231 firms that answered the two questionnaires. As a consequence, we can check if firms having CSR practices in the environmental area innovate in that domain. Only 162 firms declared themselves innovative. The proportion of large enterprises (250 employees and more) is $18.5 \%$, of industrial firms is $35.2 \%$. The percentage of firms with CSR behaviours is $25.9 \%$. Table 1 provides for the sample of 231 firms accurate information on their propensity to innovate. For instance we observe that firms that declared having CSR practices in the environmental area $3.5 \%$ do not innovate at all or $2.4 \%$ innovate but not in the environmental area. To some extent we have here 'pathological cases' in which the firm seems to demonstrate incoherent declarations. However, this total number of cases is relatively low. At the opposite we have some cases showing a reverse position. Some firms declared no participation in CSR practices in the environmental area but innovate in the environmental domain $(30.3 \%)$. These firms seem to demonstrate incoherent conduct. In fact it is not the case. These firms innovate on a voluntary basis but are basically motivated by the profit expected through the reduction of cost due to the innovation. Otherwise, we found that $34.5 \%$ of surveyed firms without CSR practices do not innovate at all or innovate outside the environmental area (15.9\%) form the standard case.

Table 1. Firm CSR and environmental innovation behaviour (\%)

\begin{tabular}{|c|c|c|c|c|}
\hline & $\begin{array}{c}\text { Non innovative } \\
\text { Firms }\end{array}$ & \multicolumn{2}{|c|}{ Innovative Firms } & Total \\
\cline { 3 - 5 } & & $\begin{array}{c}\text { Without environmental } \\
\text { benefits }\end{array}$ & $\begin{array}{c}\text { With environmental } \\
\text { benefits }\end{array}$ & \\
\hline $\begin{array}{c}\text { Firms having CSR practices } \\
\text { in the environmental area }\end{array}$ & 3.5 & 2.4 & 13.4 & 19.3 \\
\hline $\begin{array}{c}\text { Firms without CSR practices } \\
\text { in the environmental area }\end{array}$ & 34.5 & 15.9 & 30.2 & 80.7 \\
\hline Total & 38.0 & 43.6 & 18.4 & 100.0 \\
\hline
\end{tabular}

Source: CIS 2008 and CSR survey (Luxembourg). 
The CIS survey is collected by CEPS/INSTEAD on behalf of STATEC (National Statistics Institute of Luxembourg) with financial support from the European Commission (EUROSTAT). The questionnaire contains one question on "the environmental benefits from the production of goods or services within your enterprise". Nine types of benefits are suggested (see table 2). The surveyed firms were limited to 'yes' or 'no' answers. Table 2 provides the answers for the Luxemburg firms. The percentage of firms answering 'yes' varies greatly according to the questions. It must be noted these positive responses are weaker than those obtained for the French firms (Galia et al., 2012). Large firms, industrial firms, and firms possessing CSR behaviour have a markedly higher percentage of positive responses. Finally, the percentage of 'yes' answer appears weaker for the benefits related to the after sales use of a good or service by the end user (trend also evidenced for France).

Table 2. Environmental benefits stemming from firm innovation or after sale use: percent of innovating firms answering yes

\begin{tabular}{|c|c|c|c|c|}
\hline & $\begin{array}{c}\text { Total } \\
\text { population of } \\
\text { innovating } \\
\text { firms } \\
(n=162)\end{array}$ & $\begin{array}{c}\text { Population of } \\
\text { firms with } 250 \\
\text { employees and } \\
\text { more } \\
(\mathrm{n}=30)\end{array}$ & $\begin{array}{l}\text { Population of } \\
\text { industrial firms } \\
\quad(\mathrm{n}=57)\end{array}$ & $\begin{array}{c}\text { Population of } \\
\text { firms having } \\
\text { CSR } \\
\text { behaviour } \\
(\mathrm{n}=42)\end{array}$ \\
\hline \multicolumn{5}{|l|}{$\begin{array}{l}\text { Environmental benefits from the } \\
\text { production of goods or services } \\
\text { within your enterprise }\end{array}$} \\
\hline $\begin{array}{l}\text { - Reduced material use per } \\
\text { unit of output }\end{array}$ & 29.01 & 46.67 & 40.35 & 40.48 \\
\hline $\begin{array}{l}\text { - } \quad \text { Reduced energy use per } \\
\text { unit of output }\end{array}$ & 30.86 & 53.33 & 36.84 & 45.24 \\
\hline 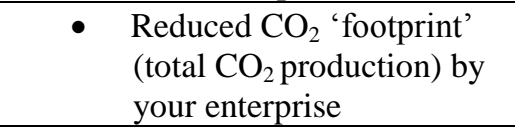 & 34.57 & 50.00 & 42.11 & 42.86 \\
\hline $\begin{array}{l}\text { - } \\
\text { leps pollaced materials with } \\
\text { substitutes }\end{array}$ & 29.63 & 40.00 & 33.33 & 35.71 \\
\hline $\begin{array}{l}\text { - Reduced soil, water, noise, } \\
\text { or air pollution }\end{array}$ & 28.40 & 43.33 & 40.35 & 35.71 \\
\hline $\begin{array}{l}\text { - Recycled waste, water, or } \\
\text { materials }\end{array}$ & 50.62 & 70.00 & 59.65 & 61.90 \\
\hline \multicolumn{5}{|l|}{$\begin{array}{l}\text { Environmental benefits from the } \\
\text { after sales use of a good or service } \\
\text { by the end user }\end{array}$} \\
\hline - $\quad$ Reduced energy use & 26.54 & 43.33 & 21.05 & 35.71 \\
\hline $\begin{array}{l}\text { - } \begin{array}{l}\text { Reduced air, water, soil or } \\
\text { noise pollution }\end{array} \\
\end{array}$ & 20.37 & 26.67 & 24.56 & 26.19 \\
\hline $\begin{array}{l}\text { - Improved recycling of } \\
\text { product after use }\end{array}$ & 29.01 & 33.33 & 31.58 & 40.48 \\
\hline
\end{tabular}

Source: CIS 2008 and CSR Survey (Luxemburg)

Of the nine types of benefits provided by the survey, each firm can indicate one or several of the nine choices. When a firm answers more than one question it means it has implemented many innovations or one innovation with great value that has presumably important consequences in terms of the environment. We were unable to determine the number of innovations implemented by a firm. We only have information on the diverse types of environmental benefits. As a consequence, the answers related to that question enable us to define a new indicator measuring the scale of the positive impacts on the environment coming 
from the firm technological innovation capacity (variable TOT). This variable can take ten modalities (from zero to nine). It offers a measure of the firm's positive impact on the environment.

We can argue that the firm contribution of environmental change is to a certain extent proportional to the firm size. A large firm will certainly implement several environmental innovations, a small one much less. Consequently, we need to control for firm size in the regressions that we ran. Table 3 provides the distribution of firms according to the different values taken by the variable TOT. The distribution is very skewed at right. We replicated this exercise for diverse populations of firms (large, industrial, having CSR conduct). Skewness is always a strong characteristic of these distributions but seemingly less marked for the three sub-samples of firms. This result indicates that firm size, belonging to industry, and implementing CSR set up variables playing positively on the values taken by variable TOT.

\section{Table 3. Variable TOT distribution according to different populations of firms (\%)}

\begin{tabular}{|c|c|c|c|c|}
\hline TOT & $\begin{array}{c}\text { Total population } \\
(\mathrm{n}=231)\end{array}$ & $\begin{array}{c}\text { Large Firm Size } \\
(\mathrm{n}=34)\end{array}$ & $\begin{array}{c}\text { Industrial Firm } \\
(\mathrm{n}=77)\end{array}$ & $\begin{array}{c}\text { Firm implementing CSR } \\
(\mathrm{n}=51)\end{array}$ \\
\hline 0 & 48.48 & 26.47 & 37.66 & 33.33 \\
\hline 1 & 9.96 & 5.88 & 10.39 & 7.84 \\
\hline 2 & 9.52 & 8.82 & 11.69 & 9.80 \\
\hline 3 & 8.66 & 17.65 & 7.79 & 13.73 \\
\hline 4 & 5.19 & 5.88 & 6.49 & 5.88 \\
\hline 5 & 5.19 & 5.88 & 10.39 & 5.88 \\
\hline 6 & 5.19 & 5.88 & 6.49 & 5.88 \\
\hline 7 & 2.16 & 2.94 & 5.19 & 3.92 \\
\hline 8 & 3.03 & 11.76 & 1.30 & 7.84 \\
\hline 9 & 2.60 & 8.82 & 2.60 & 5.88 \\
\hline
\end{tabular}

Source: CIS 2008 and CSR Survey (Luxemburg)

CIS 2008 provides also information on the motives of environmental innovation implementation. The survey asks if the enterprise introduced an environmental innovation in response to:

1. Existing environmental or expected regulations or taxes on pollution

2. Availability of government grants, subsidies or other financial incentives for environmental innovation

3. Current or expected market demand from your customers for environmental innovations

4. Voluntary codes or agreements for environmental good practice within your sector

Like the previous question, the surveyed firms could answer 'yes' to more than one item. For each of these 4 motives we defined four variables: regulation (REG), incentives (INCIT), user driven (USER), and value (VALUE). We consider the variables VALUE and CSR conduct as close but a little different. 


\section{CSR as determinant of eco-innovations: econometric analysis}

The merging of the surveys enabled us to test if CSR and firm voluntary measures for environmental change have an impact on firm eco-innovation activity. In this section we explain our econometric work by defining the variables. Then we describe different types of regressions.

\subsection{Definition of variables}

We want to determine if firm position in terms of CSR, including environmental concerns, has a positive impact on the probability of implementing environmental innovation. Therefore, from CIS 2008 we develop a set of dependent dummy variables: probability of implementing environmental innovation (INNO_ENV) and probability of introducing an innovation without any environmental benefit (INNO_NOENV).

Our main independent variable will be a dummy variable taking into account if a firm declared having a CSR position related to environmental concerns (RSEENV). It is important to control for the positive impact of other factors known as innovation drivers. Following an evolutionary frame perspective, the probability of firm innovation depends on a mix of firmspecific characteristics and sector configurations (Cohen, 1995; Teece, 2007). Firm capabilities are crucial to its long-term success and innovative performance (Teece and Pisano, 1994). A strong knowledge base includes R\&D capacity and a well-trained workforce (Cohen and Levinthal, 1989). Because R\&D expenditures are missing in our data set we capture innovation efforts by the proportion of employees with a higher education degree (EMPHI) as a proxy for the level of human capital dedicated to innovation. Another important driver relates to technological opportunities (PRODPER), which is measured by the speed in which products and services become old-fashioned. The intensity competition is acknowledged as a determinant of firm innovation. Consequently, we think it plays a positive role as far as innovation decision is concerned. In order to assess the impact of this factor we included in the model a dummy variable (MARCONC), which takes the value 1 when the competition of the market in which the firm is operating in is very intense, and otherwise a value of 0 . Many studies have acknowledged that firm size matters. For instance, large firms have enough resources to invest in knowledge activities (R\&D). We took into account firms' size through three modalities according to the European definition: T1, from 10 to 49 employees; T2, from 50 to 249 employees; and T3, more than 249 employees. It may be the sector of activity (manufacturing/services) matters. Therefore, we decided to use a dummy variable (INDUS) to control for this likely effect. We also added another less traditional control: a variable indicating whether the firm belongs to a group (GROUP). According to a survey by Mairesse and Mohnen (2010), belonging to an industrial group modifies R\&D behaviour. It gives more stability to the volume of R\&D expenditures. Consequently, we added the variable GROUP. Table 4 gives more details on the variables' precise definitions (see Appendix 1 for summary statistics of the variables). 
Table 4. List of variables

\begin{tabular}{ll}
\hline \multicolumn{1}{c}{ Variables } & \multicolumn{1}{c}{ Description } \\
\hline INNO_ENV & $\begin{array}{l}\text { Firm implement an environmental innovation which is a new or significantly } \\
\text { improved product (good or service), process, organisational method or marketing } \\
\text { method that creates environmental benefits compared to alternatives (dummy } \\
\text { variable) }\end{array}$ \\
INNO_NOENV & $\begin{array}{l}\text { Firm introduce an innovation without any environmental benefit (dummy } \\
\text { variable) }\end{array}$ \\
TOT & Number of environmental benefits declared by the firm (count variable) \\
RSEENV & Firms with environmental CSR profile (Dummy) \\
EMPHI & Percentage of employees with higher education (incl. post-secondary college and \\
REG & university) \\
INCIT & Motives for eco-innovation triggered by regulation (dummy variable) \\
USER & Motives for eco-innovation triggered by incentives (dummy variable) \\
VALUE & Motives for eco-innovation pull by user needs (dummy variable) \\
PRODPER & Motives for eco-innovation triggered firm value (dummy variable) \\
MARCONC & Products and services become rapidly old-fashioned (dummy variable) \\
T1 & Competition of the market is very intense (dummy variable) \\
T2 & Total number of employees is between 10 and 49 \\
T3 & Total number of employees is between 50 and 249 \\
INDUS & Total number of employees is more than 249 \\
GROUP & Belongs to the manufacturing sector \\
\hline & Firm is part of a group \\
\hline
\end{tabular}

Note: The main dependent variables are in bold.

\subsection{Estimation strategy}

A natural way of explaining the factors that would have an impact on a firm's decision to implement eco-innovation is to estimate a probit model. To take into account a possible relationship between the probability of implementing eco-innovation and another type of innovation, we estimated a bi-probit model. In a second step we estimated the variable TOT that measures the scale of firm commitment in an environmental behaviour (see appendix 2 for the correlation matrix of the variables).

4.3. Binary response model for the determinants of environmental innovation: Estimation results

Table 5 provides the estimation results. The coefficients are estimated by the maximum likelihood method. The main finding is a significant and positive estimated coefficient related to RSEENV in the right column indicating that a CSR attitude drives environmental innovation. However, it is an obstacle to other types of innovation (see the negative coefficient related to RSEENV in the left column). We could see here a "crowding effect": what the firm adds in terms of resources for producing and implementing environmental innovation is withdrawn from the resources dedicated to other types of innovation. As far as the other variables are concerned we note some factors playing the same role in two types of innovation: the intensity of competition (positive impact) or a low firm size (negative impact). These results were expected and highlight the coherence of our analysis. By contrast some variables positively impact environmental innovation and the reverse for the other types of innovations (INDUS, GROUP). The proxy for investing in R\&D activity (EMPHI) has an 
impact but not for the implementation of environmental innovation. One reason might be the following: many environmental innovations are not technological in essence, but due to new organizational setting which are not outputs of R\&D activity. Lastly the test done on the rho shows it differs significantly from zero. It witnesses there is a correlation between the residuals of the two equations, indicating that the two dependent variables are linked (there is at least one variable that is not in our model that has a positive effect on INNO_NOENV and at the same time a negative effect on INNO_ENV).

Table 5. The determinants of innovation behaviours (bivariate probit model)

\begin{tabular}{|c|c|c|}
\hline & \multicolumn{2}{|c|}{ Estimated coefficient (standard error) } \\
\hline & INNO_NOENV & INNO_ENV \\
\hline RSEENV & $\begin{array}{c}-0.2833627 * * * \\
(0.1004736)\end{array}$ & $\begin{array}{c}0.7578151 * * * \\
(0.0852525)\end{array}$ \\
\hline PRODPER & $\begin{array}{c}-0.1285714 \\
(0.1028923)\end{array}$ & $\begin{array}{c}0.1196936 \\
(0.0878877)\end{array}$ \\
\hline EMPHI & $\begin{array}{c}0.3388346 * * * \\
(0.1081328)\end{array}$ & $\begin{array}{c}0.1578463 \\
(0.0965268)\end{array}$ \\
\hline MARCONC & $\begin{array}{c}0.2500555 * * * \\
(0.0836939)\end{array}$ & $\begin{array}{c}0.2701721 * * * \\
(0.0711029)\end{array}$ \\
\hline $\mathrm{T} 1$ & $\begin{array}{c}-0.3475048 * * * \\
(0.0905129)\end{array}$ & $\begin{array}{c}-0.2041539 * * * \\
(0.0792182)\end{array}$ \\
\hline $\mathrm{T} 2$ & Ref. & Ref. \\
\hline T3 & $\begin{array}{l}-0.1773707 \\
(0.1655242)\end{array}$ & $\begin{array}{c}0.3934667 * * \\
(0.1599828)\end{array}$ \\
\hline INDUS & $\begin{array}{c}-0.3124579 * * * \\
(0.100751) \\
\end{array}$ & $\begin{array}{c}0.492803 * * * \\
(0.0831628) \\
\end{array}$ \\
\hline GROUP & $\begin{array}{c}-0.2824996 * * * \\
(0.0806371) \\
\end{array}$ & $\begin{array}{c}0.263583 * * * \\
(0.0693479) \\
\end{array}$ \\
\hline CONST & $\begin{array}{c}-0.6826585 * * * \\
(0.1210117) \\
\end{array}$ & $\begin{array}{c}-0.7028784 * * * \\
(0.1046264)\end{array}$ \\
\hline Sample size & \multicolumn{2}{|c|}{231} \\
\hline Sum of Weights used & \multicolumn{2}{|c|}{1650} \\
\hline -Log-likelihood & \multicolumn{2}{|c|}{-1561.6705} \\
\hline Rho & \multicolumn{2}{|c|}{$-1(4.99 e-07)$} \\
\hline Likelihood-ratio test of rho $=0$ & \multicolumn{2}{|c|}{$\operatorname{chi}^{2}(1)=414.049 \quad$ Prob $>$ chi $^{2}=0.0000$} \\
\hline
\end{tabular}

4.4. Negative binomial regression model for accounting for firm innovation impact on environment

As already said our empirical study includes information related to the environmental benefits in the production of goods or services from the enterprise. Nine possible responses were given, with the possibility that a firm could choose more than one response. We build up a quantitative count variable (variable: TOT) having ten modalities (zero included).

Our count variable produces nonnegative integer values. In this category there are only a few values (including zero). Therefore, gaussian distribution does not apply here. In the data count frame the most popular distribution is the Poisson distribution for which the mean and the variance are equal. Unfortunately, the use of the Poisson regression model requires that the Poisson law holds and therefore is very restrictive. The negative binomial regression applies when the Poisson law properties are violated. In our data the mean $=1.957$ and the variance $=$ 6.563. Consequently, we have to reject the Poisson law for modelling our variable TOT. 
We then apply the negative binomial regression to the firm innovation impact in terms of environmental innovation (see table 6). As previously stated, the dependant variable is the number of benefits (from 0 to 9 ) that the firms in the sample create for environmental innovation. We define two models in order to confirm the robustness of our results. In the regression analysis we choose as regressors the different environmental innovations motives implemented during the period 2006 to 2008. The variables previously defined are: REG, INCIT, USER, and VALUE. We also consider the variable VALUE as similar to CSR behaviour but slightly different.

In the second model we replace the four dummy variables from CIS 2008 by the binary variable RSEENV indicating if the firm has CSR behaviour in terms of environmental concerns. In order to provide an estimation of the two models we add as control variables the variables previously used in the probit model in order to control for other effects that would have affected the endogenous variable TOT, such as the strength of competition, firm membership, firm size, etc. Controlling for firm size is very important in the context of this regression since we hint the dependent variable (TOT) is significantly affected by the firm size. The coefficients are estimated by maximum likelihood.

Table 6. The determinants of firm innovation impact on environment (negative binomial model)

\begin{tabular}{|c|c|c|}
\hline & \multicolumn{2}{|c|}{$\begin{array}{c}\text { Dependent variable: TOT } \\
\text { Estimated coefficient (standard error) }\end{array}$} \\
\hline & Model 1 & Model 2 \\
\hline REG & $\begin{array}{c}0.9730433 * * * \\
(0.3061123)\end{array}$ & l \\
\hline INCIT & $\begin{array}{l}-0.797322 * * \\
(0.3393495) \\
\end{array}$ & I \\
\hline USER & $\begin{array}{c}0.1088918 \\
(0.2563029)\end{array}$ & I \\
\hline VALUE & $\begin{array}{l}1.75793^{* * *} * \\
(0.2456085)\end{array}$ & I \\
\hline RSEENV & I & $\begin{array}{c}0.782568 * * * * \\
(0.2924672)\end{array}$ \\
\hline PRODPER & $\begin{array}{c}0.296609 \\
(0.3795272)\end{array}$ & $\begin{array}{c}0.2209517 \\
(0.4239682) \\
\end{array}$ \\
\hline EMPHI & $\begin{array}{l}-0.0646916 \\
(0.3659569)\end{array}$ & $\begin{array}{l}-0.1862177 \\
(0.4486735)\end{array}$ \\
\hline MARCONC & $\begin{array}{l}0.4693927^{*} \\
(0.2600156)\end{array}$ & $\begin{array}{c}0.129851 \\
(0.303434)\end{array}$ \\
\hline $\mathrm{T} 1$ & $\begin{array}{l}-0.0808997 \\
(0.2250305)\end{array}$ & $\begin{array}{l}-0.1858323 \\
(0.246431)\end{array}$ \\
\hline $\mathrm{T} 2$ & Ref. & Ref. \\
\hline T3 & $\begin{array}{c}0.3026523 \\
(0.2697177) \\
\end{array}$ & $\begin{array}{l}0.5532807 * * \\
(0.2390227) \\
\end{array}$ \\
\hline INDUS & $\begin{array}{l}0.5179728 * \\
(0.3007552)\end{array}$ & $\begin{array}{l}0.5418384 * * \\
(0.2740964)\end{array}$ \\
\hline GROUP & $\begin{array}{c}0.0121047 \\
(0.2672718)\end{array}$ & $\begin{array}{c}0.3843951 \\
(0.2910744)\end{array}$ \\
\hline CONST & $\begin{array}{l}-1.08853 * * * \\
(0.3288068) \\
\end{array}$ & $\begin{array}{l}-0.1711497 \\
(0.3483361)\end{array}$ \\
\hline Obs. & 231 & 231 \\
\hline Log pseudo likelihood & -2292.5594 & -2580.9786 \\
\hline McFadden's Adj $\mathrm{R}^{2}$ & 0.133 & 0.025 \\
\hline
\end{tabular}

Standard error in parentheses. * Coef. significant at the threshold of $10 \%, * * 5 \%$, *** $1 \%$.

Source: Community Innovation Survey 2008 and CSR Survey (Luxembourg) 
The results of the regression analyses given in Table 6 produce interesting findings. In model 1 the motive that has the higher coefficient is firm value. An innovation driver near to CSR. Phenomena related to regulation that has a significant positive effect as well. Another interesting finding is that the incentives negatively (and significantly) influence the variable TOT. This does not mean incentives do not play a role in environmental innovation implementation. Rather, due to the variable TOT definition, they explain that firms focus much more on one specific innovation that has a limited number of environmental benefits than changes that produce several kinds of benefits. Market demand from customers has no effect on the number of environmental benefits due to firm capacity of innovation. Among the control variables the intensity of competition drives firm environmental impact but is weakly significant. This result deserves attention. It highlights in addition to different motives (regulation, value), the search for better competitive position in the industry pushes firms to increase the environmental impact of their innovation capacity. In the second model the binary variable RSEENV (the firm has a CSR behaviour related to the environment) influence positively the environmental impact of the firm innovation. Such finding supports the results from the probit model regression. However, here we do not explain the probability to innovate but the scale of the firm impact in this area. Nevertheless, its explanative power is two times less than the dummy variable VALUE. The goodness-of-fit (here measured by McFadden's Adj $\mathrm{R}^{2}$ ) related to model 2 is weaker. The estimated coefficient for the large firm variable (T3) is significant. It may take its explanative power from the removal of the variables linked to motives (present in model 1).

In summary, the two models confirm the importance of CSR (directly or through the variable VALUE) for explaining the scale of environmental changes due to firm innovation.

\section{Conclusion}

In this paper we want to contribute to the analysis of determinants of environmental innovation. We focus our study on corporate social responsibility as a crucial component of firm voluntary measures for environmental changes. Our empirical perspective is based on the joint use of a survey carried out in Luxemburg on firm CSR practices and the Community Innovation Survey 2008 (CIS 2008). We merge the surveys and examined a sample of 231 firms from Luxemburg. We estimate a probit model explaining the probability of implementing environmental innovation. The results show CSR is an important factor in explaining environmental innovation. We also contribute to the literature as follows. We utilize a question from CIS 2008 concerning the different environmental benefits from the production of goods or services within the firm or from the after sales use of a good or service by the end user. From the responses we developed a new indicator measuring the scale of the positive impacts on the environment coming from the firm innovation capacity. It is a count variable with different values from zero to nine. A negative binomial regression enabled us to estimate a significant and positive effect of CSR and firm value on the scale of the firm impacts.

Another study should seriously deal with the collinearity between the variables and study the representativeness of our firm sample. Our research agenda for the future will take more into account the point of view of economic analysis. We are aware that the firms can have different motives for introducing environmental innovations. This possibility should deserve more attention. We expect to develop a new variable or a set of new variables in order to take this fact into account. We intend to put in the negative binomial model terms of interaction for 
testing the joint impact of motives on the impacts on the environment coming from the firm technological innovation capacity.

\section{References}

Acemoglu D., Aghion P., Bursztyn L., Hemous D. (2009), The environment and directed technological change, MIT, Harvard, NBER working paper (downloaded on 17 September 2012 from <http://dash.harvard.edu/handle/1/4554221>).

Aghion P., Hemous D., Veugelers R. (2009), No green growth without innovation. Bruegel Policy Brief, 2009/07, Bruegel, Brussels.

Antonioli D., Mazzanti M. (2009), "Techno-organisational strategies, environmental innovations and economic performances. Micro-evidence from an SME-based industrial district", Journal of Innovation Economics, vol. 3, n¹, pp. 145-168.

Arundel A., Kempf R. (2009), Measuring eco-innovation, UNU-Merit working papers 2009017.

Bansal P., Roth K. (2000), "Why companies go green: A model of ecological responsiveness", The Academy of Management Journal, vol. 43, n 4, pp. 717-736.

Baron D.P. (2001), "Private politics, corporate social responsibility, and integrated strategy", Journal of Economics and Management Strategy, vol. 10, pp. 7-45.

Belin J., Horbach J., Oltra V. (2009), "Determinants and specificities of eco-innovations - An econometric analysis for France and Germany based on the Community Innovation Survey", DIME Workshop on Environmental Innovation, Industrial Dynamics and Entrepreneurship, Utrecht, The Netherlands, 10-12 Mai.

Bocquet R., Le Bas C., Mothe C., Poussing N., (2012), “Are firms with different CSR profiles equally innovative? Empirical analysis with survey data", European Management Journal. http://www.sciencedirect.com/science/article/pii/S0263237312000692.

Borghesi S., Cainelli G., Mazzanti M. (2012), The European Emission Trading Scheme and environmental innovation diffusion: Empirical analyses using Italian CIS data, Working Papers 201201, University of Ferrara, Department of Economics.

Bosetti, V., Carraro C, Duval R., Sgobbi A., Tavoni M. (2009), The Role of R\&D and technology diffusion in climate change mitigation: New perspectives using the WITCH Model, OECD Economics Department Working Paper No. 664.

Burke L., Logsdon M. (1996), "How corporate social responsibility pays off". Long Range Planning, vol. 29, nº 4, pp. 495-502.

Chassagnon V., Haned N., (2013), "Environmental Innovation and Innovation Leadership: A Firm-Level Empirical Analysis". Communication Workshop ESDES-GATE-IREGE, Mars.

Commission of the European Communities (2001), Green paper. Promoting a European framework for corporate social responsibility, $\mathrm{COM(2001)} 366$ final. 
Cohen W. (1995), "Empirical studies of innovative activity". In P Stoneman (ed.), Handbook of the Economic of Innovation and Technological Change, Blackwell, Oxford.

Cohen W., Levinthal D. (1989), "Innovation and learning: The two faces of R\&D”, Economic Journal, vol. 99, pp. 569-596.

Darnall N., Sides S. (2008), "Assessing the performance of voluntary environmental programs: does certification matter?", The Policy Studies Journal, vol. 36, n 1, pp. 95-117.

Elhauge E. (2005), Corporate managers' operational discretion to sacrifice corporate profits in the public interest', in B. Hay, R. Stavins and R. Vietor (eds), Environmental Protection and the Social Responsibility of Firms, Washington, DC, Resources for the Future.

Florida R. (1996), "Lean and green: the move to environmentally conscious manufacturing", California Management Review, vol. 39, $\mathrm{n}^{\circ}$, pp. 80-105.

Frondel M., Horbach, J., Rennings K. (2007), "End-of-pipe or cleaner production? An empirical comparison of environmental innovation decisions across OECD countries", Business Strategy and the Environment, vol. 16, n ${ }^{\circ}$, pp. 571-584.

Galia F., Ingham M., Pekovic S. (2012), Environmental benefits of forms of innovations in French manufacturing firms. 35th DRUID Celebration Conference 2013, Barcelona, Spain, June 17-19.

Garriga E., Melé D, (2004), "Corporate social responsibility theories: Mapping the territory", Journal of Business Ethics, vol. 53, pp. 51-71.

Henriques I, Sadorsky P. (2008), "Voluntary Environmental Programs: A Canadian Perspective”, Policy Studies Journal, vol. 36, n¹, pp. 143- 166.

Horbach J. (2008), "Determinants of environmental innovation - New evidence from German Panel data sources", Research Policy, vol.37, pp. 163-173.

Jaffe A., Palmer K. (1997), "Environmental regulation and innovation: A panel data study", The Review of Economics and Statistics, vol. 79, n 4, pp. 610-619.

Khanna, M. (2001), "Non-mandatory Approaches to Environmental Protection", Journal of Economic Surveys, vol. 15, n³, pp. 291-324.

Koehler D.A. (2007), "The Effectiveness of Voluntary Environmental Programs-A Policy at a Crossroads?”, Policy Studies Journal, vol. 35, n²4, pp. 689-722.

Le Bas C., Poussing N. (2012), Are complex innovators more persistent than single innovators? An empirical analysis of innovation persistence drivers. GATE WP 1201.

Lyon T.P., Maxwell J.W. (2008), "Corporate social responsibility and the environment: A theoretical perspective", Review of Environmental Economics and Policy, vol. 2, n² 2, pp. 240260. 
Mairesse J., Mohnen P. (2010), Using innovations surveys for econometric analysis, National Bureau of Economic Research, Cambridge, Mass, Working Paper 15857.

Porter M.E., Kramer M.R. (2011), The big idea. Creating value. How to reinvent capitalism -and unleash a wave of innovation and growth, Harvard Business Review, January-February.

Porter M.E., Kramer M.R. (2006), "Strategy and society", Harvard Business Review, December, pp. 77-92.

Porter M.E., Van Der Linde C. (1995), "Toward a new conception of the environmentcompetitiveness relationship", Journal of Economic Perspectives, vol.9, n ${ }^{\circ}$, pp. 97-118.

Poussing N. (2011), «La Responsabilité Sociale des Entreprises au Luxembourg: Quelle avancée ? Quels résultats », Academia Bruylant, Collection « Responsabilités d'entreprises », $\mathrm{n}^{\circ} 3$.

Potoski M., Prakash A. (2005), “Green clubs and voluntary governance: ISO 14001 and firm's regulatory compliance”, American Journal of Political Science, vol. 49, n², pp. 235-248.

Reinhardt F.L., Stavins R.N. (2010), "Corporate social responsibility, business strategy, and the environment”, Oxford Review of Economic Policy, vol. 26, n², pp.164-181.

Schumpeter J. (1947), "The creative response in economic history", Journal of Economic History, vol. 7, pp. 149-59.

Teece D. (2007), "Explicating dynamic capabilities: The nature and micro-foundations of (sustainable) enterprise performance”, Strategic Management Journal, vol. 28, n³, 13191350.

Teece D.J., Pisano G. (1994), "The dynamic capabilities of firms: An introduction”, Industrial and Corporate Change, vol. 3, pp. 537-556.

Veugelers R. (2012), "Which policy instruments to induce clean innovating?", Research Policy, vol. 41, $\mathrm{n}^{\circ}$ 10, pp. 1770-1778.

Wagner M. (2007), The Link between environmental innovation, patents, and environmental management, DRUID Working Papers, $n^{\circ} 07-14$.

Wagner M. (2008), Links between sustainability-related innovation and sustainability management, SFB 649 Discussion Papers SFB649DP2008-046, Sonderforschungsbereich 649, Humboldt University, Berlin, Germany.

Ziegler A., Nogareda J.S. (2009), "Environmental management systems and technological environmental innovations: Exploring the causal relationship", Research Policy, vol. 38, n5, pp. 885-893.

Ziegler A., Rennings K. (2004), Determinants of environmental innovations in Germany: Do organizational measures matter? A discrete choice analysis at the firm level, ZEW Discussion Papers 04-30, ZEW - Zentrum für Europäische Wirtschaftsforschung / Center for European Economic Research. 
Appendix 1. Summary statistics of the variables for the full sample and the sub-sample of Responsible firms (means, standard deviation in bracket)

\begin{tabular}{|c|c|c|c|c|}
\hline \multirow[b]{2}{*}{ Variable } & \multicolumn{2}{|c|}{ Extreme observations } & \multirow{2}{*}{$\begin{array}{c}\begin{array}{c}\text { Population } \\
(\mathrm{N}=231)\end{array} \\
\text { Means } \\
\text { (Std deviation) }\end{array}$} & \multirow{2}{*}{$\begin{array}{c}\text { Responsible Firms } \\
(\mathrm{N}=51) \\
\text { Means } \\
\text { (Std deviation) }\end{array}$} \\
\hline & Min & Max & & \\
\hline INNO_ENV & 0 & 1 & $\begin{array}{c}0.51515152 \\
(0.50085566)\end{array}$ & $\begin{array}{c}0.66666667 \\
(0.47609523)\end{array}$ \\
\hline INNO_NOECO & 0 & 1 & $\begin{array}{c}0.18614719 \\
(0.39007062)\end{array}$ & $\begin{array}{c}0.15686275 \\
(0.36729002)\end{array}$ \\
\hline TOT & 0 & 9 & $\begin{array}{l}1.95670996 \\
(2.5619007)\end{array}$ & $\begin{array}{c}3 \\
(3.01993377)\end{array}$ \\
\hline RSEENV & 0 & 1 & $\begin{array}{c}0.22077922 \\
(0.41567263)\end{array}$ & $\begin{array}{c}1 \\
(0)\end{array}$ \\
\hline REG & 0 & 1 & $\begin{array}{c}0.15584416 \\
(0.36349517)\end{array}$ & $\begin{array}{c}0.29411765 \\
(0.46017899)\end{array}$ \\
\hline INCIT & 0 & 1 & $\begin{array}{c}0.03896104 \\
(0.19392234)\end{array}$ & $\begin{array}{c}0.05882353 \\
(0.23763541)\end{array}$ \\
\hline USER & 0 & 1 & $\begin{array}{c}0.10822511 \\
(0.31133913)\end{array}$ & $\begin{array}{c}0.17647059 \\
(0.38501337)\end{array}$ \\
\hline VALUE & 0 & 1 & $\begin{array}{c}0.33766234 \\
(0.47393972)\end{array}$ & $\begin{array}{c}0.58823529 \\
(0.49705012)\end{array}$ \\
\hline PRODPER & 0 & 1 & $\begin{array}{c}0.13419913 \\
(0.34160635)\end{array}$ & $\begin{array}{c}0.05882353 \\
(0.23763541)\end{array}$ \\
\hline EMPHI & 0 & 1 & $\begin{array}{c}0.32701299 \\
(0.35130959)\end{array}$ & $\begin{array}{c}0.34254902 \\
(0.30424886)\end{array}$ \\
\hline MARCONC & 0 & 1 & $\begin{array}{c}0.63636364 \\
(0.48209031)\end{array}$ & $\begin{array}{l}0.64705882 \\
(0.4826398)\end{array}$ \\
\hline T1 & 0 & 1 & $\begin{array}{c}0.42424242 \\
(0.49530071)\end{array}$ & $\begin{array}{c}0.19607843 \\
(0.40097919)\end{array}$ \\
\hline $\mathbf{T 2}$ & 0 & 1 & $\begin{array}{l}0.42857143 \\
(0.4959463)\end{array}$ & $\begin{array}{c}0.52941176 \\
(0.50410083)\end{array}$ \\
\hline T3 & 0 & 1 & $\begin{array}{c}0.14718615 \\
(0.35506075)\end{array}$ & $\begin{array}{c}0.2745098 \\
(0.4507075)\end{array}$ \\
\hline INDUS & 0 & 1 & $\begin{array}{l}0.33333333 \\
(0.4724282)\end{array}$ & $\begin{array}{l}0.35294118 \\
(0.4826398)\end{array}$ \\
\hline GROUP & 0 & 1 & $\begin{array}{c}0.58008658 \\
(0.49461622)\end{array}$ & $\begin{array}{c}0.70588235 \\
(0.46017899)\end{array}$ \\
\hline
\end{tabular}


Appendix 2. Correlation matrix of the variables

Pearson Correlation Coefficients, $\mathbf{N}=\mathbf{2 3 1}$

Prob $>|\mathbf{r}|$ under H0: Rho=0

\begin{tabular}{|c|c|c|c|c|c|c|c|c|c|}
\hline & INNO_ENV & $\begin{array}{c}\text { INNO_NO } \\
\text { ECO }\end{array}$ & RSEENV & REG & INCIT & $\begin{array}{l}\text { USER } \\
\end{array}$ & VALUE & PRODPER & EMPHI \\
\hline INNO_ENV & 100.000 & $\begin{array}{c}-0.49297 \\
<.0001\end{array}$ & $\begin{array}{c}0.16137 \\
0.0141\end{array}$ & $\begin{array}{c}0.41684 \\
<.0001 \\
\end{array}$ & $\begin{array}{c}0.19534 \\
0.0029\end{array}$ & $\begin{array}{c}0.33797 \\
<.0001\end{array}$ & $\begin{array}{c}0.63774 \\
<.0001 \\
\end{array}$ & $\begin{array}{c}0.05159 \\
0.4351 \\
\end{array}$ & $\begin{array}{c}0.06735 \\
0.3081\end{array}$ \\
\hline INNO_NOECO & & 100.000 & $\begin{array}{c}-0.04005 \\
0.5448\end{array}$ & $\begin{array}{c}-0.20549 \\
0.0017\end{array}$ & $\begin{array}{c}-0.09629 \\
0.1446\end{array}$ & $\begin{array}{c}-0.16661 \\
0.0112\end{array}$ & $\begin{array}{c}-0.27092 \\
<.0001\end{array}$ & $\begin{array}{c}-0.02514 \\
0.7039\end{array}$ & $\begin{array}{c}0.15193 \\
0.0209\end{array}$ \\
\hline RSEENV & & & 100.000 & $\begin{array}{c}0.20292 \\
0.0019\end{array}$ & $\begin{array}{c}0.05464 \\
0.4085\end{array}$ & $\begin{array}{c}0.11693 \\
0.0761\end{array}$ & $\begin{array}{c}0.28203 \\
<.0001\end{array}$ & $\begin{array}{c}-0.11771 \\
0.0742\end{array}$ & $\begin{array}{c}0.02359 \\
0.7214\end{array}$ \\
\hline REG & & & & 100.000 & $\begin{array}{c}0.34525 \\
<.0001 \\
\end{array}$ & $\begin{array}{c}0.50343 \\
<.0001 \\
\end{array}$ & $\begin{array}{c}0.45035 \\
<.0001 \\
\end{array}$ & $\begin{array}{c}-0.09913 \\
0.1330 \\
\end{array}$ & $\begin{array}{c}-0.06648 \\
0.3144 \\
\end{array}$ \\
\hline INCIT & & & & & 100.000 & $\begin{array}{c}0.43395 \\
<.0001 \\
\end{array}$ & $\begin{array}{c}0.28200 \\
<.0001 \\
\end{array}$ & $\begin{array}{c}-0.01364 \\
0.8367 \\
\end{array}$ & $\begin{array}{c}-0.03594 \\
0.5868 \\
\end{array}$ \\
\hline $\begin{array}{l}\text { USER } \\
\end{array}$ & & & & & & 100.000 & $\begin{array}{c}0.42897 \\
<.0001 \\
\end{array}$ & $\begin{array}{c}0.02637 \\
0.6901 \\
\end{array}$ & $\begin{array}{c}-0.00339 \\
0.9591 \\
\end{array}$ \\
\hline VALUE & & & & & & & 100.000 & $\begin{array}{c}0.04115 \\
0.5337 \\
\end{array}$ & $\begin{array}{c}0.04604 \\
0.4863 \\
\end{array}$ \\
\hline NPRODPER & & & & & & & & 100.000 & $\begin{array}{c}0.16131 \\
0.0141 \\
\end{array}$ \\
\hline EMPHI & & & & & & & & & 100.000 \\
\hline
\end{tabular}

\begin{tabular}{|c|c|c|c|c|c|c|}
\hline \multicolumn{7}{|c|}{$\begin{array}{c}\text { Pearson Correlation Coefficients, } \mathrm{N}=231 \\
\text { Prob }>|\mathbf{r}| \text { under H0: Rho }=0\end{array}$} \\
\hline & MARCONC & PETITE & MOY & GRDE & INDUS & GROUPE \\
\hline \multirow[t]{2}{*}{ INNO_ENV } & 0.02292 & -0.14871 & 0.01750 & 0.18300 & 0.15312 & 0.21008 \\
\hline & 0.7290 & 0.0238 & 0.7913 & 0.0053 & 0.0199 & 0.0013 \\
\hline \multirow[t]{2}{*}{ INNO_NOECO } & 0.03783 & -0.00546 & 0.03532 & -0.04172 & -0.12583 & -0.04380 \\
\hline & 0.5672 & 0.9343 & 0.5933 & 0.5281 & 0.0562 & 0.5077 \\
\hline \multirow[t]{2}{*}{ RSEENV } & 0.01183 & -0.24574 & 0.10847 & 0.19129 & 0.02214 & 0.13567 \\
\hline & 0.8580 & 0.0002 & 0.1001 & 0.0035 & 0.7378 & 0.0394 \\
\hline \multirow[t]{2}{*}{ REG } & -0.07218 & -0.24808 & 0.11025 & 0.19206 & 0.10127 & 0.12374 \\
\hline & 0.2746 & 0.0001 & 0.0946 & 0.0034 & 0.1248 & 0.0604 \\
\hline \multirow[t]{2}{*}{ INCIT } & 0.01268 & -0.17284 & -0.03875 & 0.29523 & 0.04746 & 0.08065 \\
\hline & 0.8479 & 0.0085 & 0.5579 & $<.0001$ & 0.4729 & 0.2220 \\
\hline \multirow[t]{2}{*}{ USER } & 0.00263 & -0.12987 & -0.04827 & 0.24859 & -0.00985 & 0.15523 \\
\hline & 0.9682 & 0.0487 & 0.4653 & 0.0001 & 0.8816 & 0.0182 \\
\hline \multirow[t]{2}{*}{ VALUE } & -0.01211 & -0.20542 & 0.02907 & 0.24596 & 0.03884 & 0.27363 \\
\hline & 0.8548 & 0.0017 & 0.6603 & 0.0002 & 0.5570 & $<.0001$ \\
\hline \multirow[t]{2}{*}{$\begin{array}{l}\text { PRODPER } \\
\end{array}$} & 0.08640 & 0.12459 & -0.05866 & -0.09187 & -0.06286 & 0.02618 \\
\hline & 0.1907 & 0.0587 & 0.3748 & 0.1640 & 0.3415 & 0.6923 \\
\hline \multirow[t]{2}{*}{ EMPHI } & 0.00639 & -0.05640 & 0.03982 & 0.02306 & -0.37618 & 0.15789 \\
\hline & 0.9230 & 0.3935 & 0.5471 & 0.7274 & $<.0001$ & 0.0163 \\
\hline \multirow[t]{2}{*}{ MARCONC } & 100.000 & 0.04800 & -0.05455 & 0.00924 & -0.09545 & 0.10443 \\
\hline & & 0.4678 & 0.4092 & 0.8890 & 0.1481 & 0.1134 \\
\hline \multirow[t]{2}{*}{ PETITE } & & 100.000 & -0.74339 & -0.35661 & -0.08671 & -0.35226 \\
\hline & & & & & & $<.0001$ \\
\hline MOY & & & 100.000 & -0.35978 & 0.11134 & 0.22282 \\
\hline \multirow{3}{*}{ GRDE } & & & & & & \\
\hline & & & & 100.000 & -0.03456 & 0.18016 \\
\hline & & & & & 0.6013 & 0.0060 \\
\hline \multirow[t]{2}{*}{ INDUS } & & & & & 100.000 & 0.06202 \\
\hline & & & & & & 0.3480 \\
\hline GROUPE & & & & & & 100.000 \\
\hline
\end{tabular}

